\title{
THE PRINCIPLES OF FREE VERSE IN ENGLISH
}

\author{
MARTin J. DufFell
}

Resumen: Este artículo defiende que el rasgo clave del verso libre inglés (FV) es que emplea más contrastes y menos equivalencias entre las unidades lingüísticas y métricas que el verso tradicional. Se traza el desarrollo del verso libre desde algunos de los más viejos modos de versificar en inglés: el metro basado en la frase [phrasal metre] (como en la Versión Autorizada de la Biblia), el dol'nik [verso acentual] (como en el metro de la balada inglesa), los ritmos libres (como en Dover Beach de Arnold), el verso polimétrico (como en Alexander's Feast de Dryden) y el verso regular silábico-acentual. El artículo presenta una serie de principios observados por los poetas del verso libre en inglés, cuantificando, dentro de lo posible, y citando ejemplos bien conocidos y no protegidos por derechos de autor.

Palabras clave: Verso libre, contrastes y equivalencias lingüísticas, metro basado en la frase, metro lineal, regularidad rítmica, polimetría, sistemas métricos.

Abstract: This article argues that the key feature of English free verse (FV) is that it employs more contrasts and fewer matches between linguistic and metrical units than does traditional verse. It traces the development of FV from a number of older modes of versifying in English, including phrasal metre (as in the Authorised 
Version of the Bible), the dol'nik (as in English ballad meter), free rhythms (as in Arnold's Dover Beach), polymetric verse (as in Dryden's Alexander's Feast), and regular stress-syllabic verse. The article offers a list of principles that composers of FV in English have observed, quantifying wherever possible, and quoting well-known examples that are not under copyright.

Key words: Free Verse, linguistic matches and contrasts, phrasal metre, linear metre, rhythmic regularity, polymetry, metrical systems. 


\section{INTRODUCTION}

\} $\mathrm{N}$ their recent book on poetic metre Nigel Fabb and Morris Halle argue that free verse (henceforth FV) is 'nonmetrical', and that readers must discover for themselves the units and principles on which each individual FV poem is based $^{1}$. A number of other metrists, however, have attempted to identify those units and discover whether there are any general principles for organising them in $\mathrm{FV}^{2}$. This should not be too difficult a task, since the units can only be those of the English language, and the principles are likely to have been derived from those of regular verse, if only because so many lines of FV are indistinguishable from it. This article sets out to build upon the work of earlier writers by listing and illustrating a set of general principles on which FV poets versify. This exercise will be prefaced by a brief linguistic and historical survey of the English metres that were FV's antecedents. I am unable to quote as many actual passages

${ }^{1}$ See FABB, Nigel \& HALLE, Morris: Meter in Poetry: A New Theory. Cambridge: Cambridge Univ. Press, 2008, pp. 3-4.

2 Those that focus on FV in English include HRUSHOVSKI, Benjamin: "On Free Rhythms in Modern Poetry: Preliminary Remarks towards a Critical Theory of Their Structures and Function", in Thomas A. Sebeok (ed), Style in Language. Boston: MIT Press, 1960, pp. 173-90; FRASER, G. S.: Metre, Rhyme and Free Verse. London: Methuen, 1970; HARTMAN, Charles O.: Free Verse: An Essay on Prosody. Princeton: Princeton Univ. Press, 1980; ATTRIDGE, Derek: "Poetry Unbound: Observations on 'Free verse"", Proceedings of the British Academy, 1987, 73, pp. 353-74; and HOBSBAUM, Philip: Metre, Rhythm and Verse Form. London and New York: Routledge, 1996. A comparison of English FV and Spanish verso libre can be found in DUFFELL, Martin J.: "The Liberated Line: Versifying in the Twentieth Century". Hispanic Research Journal, 2009, 10 , pp. 157-73. 
of FV in support of my analysis as I should wish, because of international copyright laws, but I shall compensate by illustrating as many of my points as possible from the work of the only major FV poet to have died more than seventy years ago $^{3}$. I shall also cite without quotation the FV of other poets whose work is under copyright but may be easily accessed in libraries, and I shall provide statistics for a number of important FV poems.

\section{LANGUAGE}

Verse is a stylisation of language, which is to say that it is language employed for a special purpose, such as poetry, song lyrics, greetings cards, and learning by rote. Verse differs from speech, and from prose (another stylisation, closer to speech than verse) in that versifiers set out to modify an aspect of language that in speech is largely random. We can divide all human utterances into linguistic units that either resemble or differ from the previous unit, that is, each represents either a match or a contrast ${ }^{4}$. The units concerned may match or contrast in various ways, the most important of which are in meaning, in grammatical function, and in size. For example, in the phrase 'Friends, Romans, countrymen' the words match semantically: they are all synonyms for members of the audience; they also match grammatically: they are plural nouns in the vocative case; but they contrast in size: each word contrasts with its predecessor by having an extra syllable.

Syllables, like words, are linguistic units of a particular size, and both may be arranged with units of other sizes in a

$\overline{3}$ For the poems of David Herbert LAWRENCE (b. 1885, d. 1930) see D. H. Lawrence: Complete Poems, ed. Vivian de Sola Pinto \& Warren Roberts, 2 vols. London: Heinemann, 1964.

${ }^{4}$ I use the term match (antonym: contrast) to describe similarity (difference) between linguistic units. Generative metrists use the term match (antonym: mismatch) in a more specialist sense, to designate a match between a verse instance and its template. 
prosodic hierarchy, as shown in the following table, derived from a modern linguistic study of the oldest metre employed in English ${ }^{5}$ :

Table A: The Prosodic hierarchy

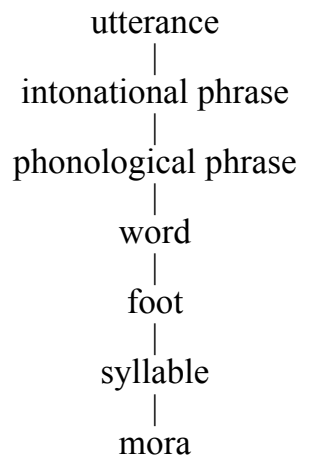

Four of these terms require some explanation: intonational phrases usually combine several phonological phrases; feet are rhythmic groups of either two or three consecutive syllables; and a mora is the duration of the shortest syllables (like $a$ and the in English, where lexical words such as nouns and adjectives must be of two moras minimum). Any speaker seeking to match utterances, phrases, words, feet, syllables, or moras can do so fairly easily, but in normal speech matches are much less common than contrasts. Prosodic contrasts are so clearly regarded as the norm that when English speakers rhyme syllables by accident they sometimes exclaim 'Gosh! I'm a poet and didn't know it' (rhyme being one of the most conspicuous ways of matching syllables). Not only are the matches and contrasts of normal speech random, but its contrasts also greatly outnumber its matches ${ }^{6}$.

${ }^{5}$ See GETTY, Paul: The Meter of 'Beowulf': A Constraint-Based Approach. New York: Mouton de Gruyter, 2002, p. 7.

${ }^{6}$ Since the remainder of this article is devoted to an analysis of prosodic matches / contrasts, I can save space by not repeating the word prosodic. 


\title{
3. VERSE
}

In terms of the binary division discussed above, verse may be distinguished from normal speech by the vastly greater number of prosodic matches found in its language. There is an established set of terms for the prosodic levels as they occur in verse, and they parallel the hierarchy above:

\section{TABLe B The hiERARChy of MetricAl Units}

\author{
strophe

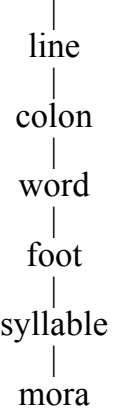

Note that modern European poets have neglected much of the potential for matching at word and mora level ${ }^{7}$. They have cultivated both matches and contrasts at strophe level: matching strophes are usually termed stanzas, contrasting ones are known as laisses or verse paragraphs ${ }^{8}$. Matches and contrasts at colon level occur mainly in longer lines, where the units concerned are termed hemistichs, or half-lines.

$\overline{7}$ Some primitive and ancient versifiers matched whole words, but modern European poets mostly match only the final syllables of words in rhyme; some Ancient Greek poets matched moras and most Japanese poets still do; see DUFFELL, Martin J.: A New History of English Metre. Oxford: Legenda, 2008, pp. 15-17.

8 The laisses of medieval French chansons de gestes were linked by assonance; see KASTNER, E.: A History of French Versification. Oxford: Oxford Univ. Press, 1903, p. 40; for examples of verse paragraphs see Paradise Lost by John MILTON (b. 1608, d. 1674) in The Complete Poems, ed. John Leonard. Harmondsworth: Penguin Books, 1998. I shall not attempt to analyse the way that poets match and contrast strophes in this article; some FV poets sometimes make this compositional choice, presumably upon the same groounds as poets writing regular verse. 
The most important of these levels, however, is undoubtedly the line, because all versifiers engineer matches and contrasts at line level. One definition of verse is 'numerically regulated language', that is to say it involves counting, and all verse divides into lines, units that stretch from where that counting begins to where it ends ${ }^{9}$. Lines of verse generally match in ways that sentences in speech do not, and the most important of these ways is in the number and / or quality of their syllables. In English that quality depends upon stress, which is a combination of volume, duration, and pitch change. English speakers deliver their syllables with varying amounts of stress, so that their utterances form a series of peaks in stress and troughs between them. Different schools of linguistic metrics employ different terminology to describe the way that syllables, peaks, and troughs correspond to the pattern in the poet's head that we call metre. For simplicity I shall use a rhythmic description and call the peaks of stress in verse beats and the troughs intervals ${ }^{10}$. Some metrical descriptions focus on the foot, a combination of a beat with specified syllables in a trough, and this is very helpful in explaining some metres ${ }^{11}$. But the foot is an unnecessary complication in the explanation of others and adds little to the analysis of FV, so I shall employ a rhythmic description, in terms of beats and intervals, for all types of English verse ${ }^{12}$.

${ }^{9}$ For these definitions see LOTZ, John: "Metric Typology", in Style in Language, pp. 135-48, and FABB, Nigel: Language and Literary Structure: The Linguistic Analysis of Forms in Verse and Narrative. Cambridge: Cambridge Univ. Press, 2002, pp. 48-49.

10 I borrow the term beat from ATTRIDGE, Derek: The Rhythms of English Poet$r y$. London: Longman, 1982; I borrow the term interval from TARLINSKAJA, Marina: English Verse: Theory and History. The Hague: Mouton, 1976.

11 For a foot-based analysis of the iambic pentameter see HANSON, Kristin, \& KIPARSKY, Paul: “A Parametric Theory of Poetic Meter". Language, 1996, 72, pp. 287-335.

12 I shall treat the onset of the line and its first beat as having an anacrusic interval (a term borrowed from Ancient Greek metrics and music). In many English metres poets have regarded anacrusic syllables as optional, including the first octosyllabics composed in England, Chaucer's iambic pentameters, and all ternary metres (those with beats on every third syllable); see DUFFEL: $A \mathrm{New}$ History, cit., pp. 76, 88, \& 178-81. The modern flexible pentameter includes many of Chaucer's 'headless' lines, which are also distortions of the canonical line, often with a trochaic rhythm; see Table G. 


\section{Strict Metres}

Fabb and Halle make the useful distinction between strict and loose metres, and English strict metres belong to the class termed stress-syllabic ${ }^{13}$. The most popular English stress-syllabic metre is the iambic pentameter, a line of ten total syllables with five beats. Its name derives from the fact that poets and critics have traditionally perceived its lines as being based on a pattern, or template, of five iambic feet (weak-before-strong pairs). Ezra Pound caricatured the rhythm of the iambic pentameter as 'ti-tum-ti-tum-ti-tum-ti-tum-ti-tum', implying that each beat in the line is preceded by a single syllable, to match the template's iambic feet ${ }^{14}$. But this is clearly not the case, as can be seen from the following lines from Tennyson's iambic pentameter poem 'Ulysses' ${ }^{15}$ :

(1) Much have I seen and known: ci-ties of men

(2) And man-ners, cli-mates, coun-cils, go-vern-ments

(3) Lit-tle re-mains: but e-very hour is saved

(4) The thun-der and the sun-shine, and op-posed

Only instance (2) is indisputably iambic: all its even-numbered syllables are strong syllables in polysyllabic words and clearly represent beats. In (4) the iambic rhythm depends on treating the word 'and' (on two occasions) as a beat by default: it is not stressed in normal speech, but here it is in a position where the ear anticipates a beat, and neither of its neighbours can supply one. In (1) and (3) beats occur on oddnumbered syllables: in (1) there is a monosyllabic beat on the first syllable and a lexical stress on the seventh, while in (3) there is a lexical stress on the first syllable.

$\overline{13}$ See FABB \& HALLE: Meter in Poetry, cit., pp. 43 \& 67.

14 This caricature of the iambic pentameter first appeared in "Treatise on Metre" by Ezra POUND (b. 1885, d. 1972); see his ABC of Reading. London: Faber and Faber, 1961, p. 203.

15 For the poems of Alfred TENNYSON (b. 1807, d. 1890), see his Poems and Plays. London: Oxford Univ. Press, 1953; I employ the following scansion aids throughout this article: syllables that are separately counted are hyphenated, the strong syllables of polysyllabic words (those with primary stress) are given in bold typeface, monosyllables and secondary stresses that become beats are underlined. 
Note that inversions, as these beats on odd-numbered syllables are usually termed, are almost always initial inversions, in that they either open the line or follow its chief syntactic boundary. Inversions do not alter the total number of syllables in the line, but produce deviant intervals, one of two, the other of zero syllables: this is an even more obvious departure from the strict rhythm than is produced by default beats in (4). Inversions and default beats are the chief forms of tension, permissible variation between template and verse instance, in the strict iambic pentameter ${ }^{16}$. But still more rhythmic variety is possible if iambic pentameters are not quite so strict, as I shall demonstrate in the next section.

\section{Loose Metres}

My definition of the term loose with regard to metres differs somewhat from that of Fabb and Halle. Thus I classify the metre of Beowulf as loose, for the same reason that they describe the metre of the Iliad in this way: because the number of syllables in its weak positions varies. In order to be consistent English metres should be classed as strict if they regulate both the number of beats and the size of the intervals between them, and loose if they regulate one of these features but not the other. Fabb \& Halle focus their analysis on what they term loose iambic metres, those that regulate the number of beats, but allow the intervals between them to vary. I prefer the term dolniks for these metres, first because it is much shorter, and secondly one-syllable intervals do not necessarily constitute the majority in these metres, nor does an iambic rhythm always predominate ${ }^{17}$.

A good example of an English dolnik is the metre of Browning's poem 'The Statue and the Bust', which opens

$\overline{16}$ A number of writers have commented upon this balancing between matches and contrasts in verse; the most concise was Auguste DORCHAIN, who refined an observation of Baudelaire's and said that the human mind seems to seek both sécurité and surprise in verse, the first to re-assure and the second to stimulate; see DORCHAIN, Auguste: L'Art des vers. Paris: Garnier, 1919, pp. 22-23.

17 I borrow the Russian term dol'nik (which I have anglicized) from TARLINSKAJA: English Verse Theory and History, cit. 
with the following lines ${ }^{18}$ :

(5) There's a pa-lace in Flo-rence, the world knows well,

(6) And a sta-tue wat-ches it from the square,

(7) And this sto-ry of both do our towns-men tell.

The metre of this poem is a four-beat dolnik, and seven of the intervals in the quotation contain two syllables, while only five intervals contain one. The dolnik is intermediate, both in typology and chronology, between iambic metres (with their normal intervals of one) and the accentual metres of Old English (with intervals that could stretch to four syllables). Although they evolved from dolniks, stress-syllabic metres never replaced them, and some poets continued to employ dolniks in every period ${ }^{19}$. They are the staple of folk verse, such as proverbs and nursery rhymes, and they have often been employed for short lyric poems; they were also the metres of the earliest English dramas.

Even after the unrhymed iambic pentameter (blank verse) became the norm in drama in the second half of the sixteenth century, dramatists continued to hanker after the illusion of normal speech that varying the size of intervals produces. Thus, although Shakespeare composed his sonnets in strict iambic pentameters, he used a much looser variant of the metre in his plays: some of the intervals in their lines contain an extra syllable. Shakespeare makes his dramatic lines more like normal speech by a skilful combination of inversion, default beats, and this practice, which is often called substitution or resolution ${ }^{20}$. His younger contemporary John Webster went even further in loosening the metre, and half of his lines contain at least one interval of more than one syllable. The following lines from The Duchess of Malfi

$\overline{18}$ For this poem by Robert BROWNING (b. 1812, d. 1889) see Robert Browning: Poems 1833-1864, ed. Ian Jack. London: Oxford Univ. Press, 1970.

${ }^{19}$ See TARLINSKAJA: English Verse Theory and History, cit., p. 128, and DUFFELL: A New History, cit., pp. 65-66.

${ }^{20}$ See George WRIGHT, T.: Shakespeare's Metrical Art. Berkeley, CA: Univ. of California Press, 1988. 
(IV.1, 42-44) show how different such looser lines could be from the iambic template ${ }^{21}$ :

(8) For though our na-tionall law dis-tin-guish Bas-tards

(9) From true le-gi-ti-mate is-sue; com-pas-sio-nate na-ture

(10) Makes them all e-quall.

Instance (8) is a canonical iambic pentameter providing 'na-tionall is two syllables, but (9) qualifies as a five-beat dolnik, because three of its intervals are candidates for containing more than a single syllable, and at least one of them ('-sue com') cannot be explained by syncope.

A quite different type of loose English metre also appears chiefly in blank-verse drama: and I have counterfeited this looseness in instance (10) by not completing Webster's tensyllable line. Elizabethan and Jacobean dramatists sometimes included a shortened line of four, six, or eight syllables to break up the regularity of their blank verse still further. Alternatively, they allowed another speaker to complete a line, reproducing the sort of interruption that is a feature of much normal dialogue. A metre with such shortened and divided lines is loose in the converse way to dolnik metres: the intervals are regular but the number of beats varies. Russian metrists have a term for this too; they describe such metres as free rhythms, and when the rhythm is iambic they are free iambs. Few English poets had employed free iambs outside drama until the advent of free verse, but one famous example of the metre is Matthew Arnold's poem 'Dover Beach' (1867), which opens with the following lines ${ }^{22}$ :

(11) The sea is calm to-night,

(12) The tide is full; the moon lies fair

(13) U-pon the Straits; on the French coast the light

(14) Gleams and is gone; the cliffs of Eng-land stand

These lines contain their fair share of tension but Nigel

$\overline{{ }^{21}}$ For the plays of John WEBSTER (b. c. 1578, d. c.1632) see The Complete Works of John Webster, ed. F. L. Lucas, 4 vols. London: Chatto \& Windus, 1927.

${ }^{22}$ For the poems of Matthew ARNOLD (b. 1822, d. 1888) see The Poems of Matthew Arnold, ed. K. Allot \& M. Allott. London: Longman, 1977. 
Fabb also notes that Arnold's varied line lengths enable the text to be recombined into canonical pentameters ${ }^{23}$. For example, one such recombination would run from 'The sea' in (11) to 'full' in (12) and another from 'on' in (13) to 'gone' in (14).

Twentieth-century poets writing in English included both dolniks and free iambs in their FV, as I shall describe in detail below.

\section{Polymetry}

English poets have mostly employed a single verse design in any given poem, but quite often they have employed two (for example, Spenser combined iambic pentameters and hexameters in the stanza that bears his name) ${ }^{24}$; they have more rarely resorted to more than two. Restoration and $\mathrm{Au}-$ gustan poets, however, were greatly impressed by the craftsmanship of the Greek poet Pindar and sought to imitate his polymetry in odes with long strophes containing lines of many different lengths. For the most part they made these poems iambic in rhythm (like Arnold's 'Dover Beach'), and they placed lines of each length in corresponding positions in the strophe (as in the Spenserian stanza). One poet, however, John Dryden (b. 1631, d. 1700) composed two great odes that were metrically much more ambitious, his Ode for St Cecilia's Day (1687) and Alexander's Feast (1697) ${ }^{25}$. In these poems he went much further than Spenser or Arnold, by varying both the number of beats in the line and the size of the intervals between them.

In Alexander's Feast, in particular, Dryden employed lines

23 See FABB, Nigel: "The Metres of Dover Beach". Language and Literature, 2002, 11, pp. 99-117.

${ }^{24}$ For the use of this stanza by Edmund SPENSER (b. 1552, d. 1599) see The Selected Poetry of Spenser, ed. A.C. Hamilton. New York: New American Library, 1966.

${ }^{25}$ For Alexander's Feast by John DRYDEN (b. 1631, d. 1700), which was set to music by Handel, see The Poems of John Dryden, Volume 5, 1697-1700, ed. Paul Hammond \& D. Hopkins. London: Longman, 2005. 
of many different lengths and rhythms, as can be seen from the following examples:
(15) 'Twas at the ro-yal feast, for Per-sia won
(1) [iambic tetrameter]
(16) By Phi-lip's war-like son
(2) [iambic trimeter]
(17) Their brows with ro-ses and with my-rtles bound
(7) [iambic pentameter]
(18) Hap-py, hap-py, hap-py, pair
(12) [trochaic tetrameter catalectic]
(19) Rich the trea-sure
(58) [trochaic dimeter]
(20) Soft-ly sweet, in Ly-dian mea-sures
(97) [trochaic tetrameter]
(21) And the spar-kles that flash from their eyes
(22) Those are Gre-cian ghosts, that in bat-tle were slain
(135) [anapaestic trimeter]

(23) And the king seiz'd a flam-beau with zeal to des-troy

(138) [four-beat dolnik?]

(151) [anapaestic tetrameter]

In the poem as a whole 70 per cent of lines are iambic, 19 per cent are trochaic, and 11 percent are anapaestic ${ }^{26}$. Instance (22) is the only candidate for a dolnik, but a diaeresis in 'Greci-an' would render it anapaestic. Six different line lengths occur in the poem, and the most common length (measured in beats) is four, and after that three; no strophe contains fewer than four different lengths. The poem thus presents many prosodic contrasts, while its matches are fewer and local: lines with the same rhythm are more often clustered than separated and each of the strophes has a different, often intricate rhyme scheme.

The important points to note about this polymetric poem are that Dryden's lines are rhymed, that all the metres involved are stress-syllabic, and that there is a systematic ordering of the rhythms and line lengths. Before the advent of free verse I can find no example in English of a poet applying polymetry unsystematically to unrhymed dolniks. That was the step that English versifying took only with the advent of $\mathrm{FV}$, and it proved one of the major developments in the history of English metre.

\footnotetext{
$\overline{26}$ Since Dryden's poem imitates a Classical Greek form, I label his lines not according to their number of beats, but by the Classical terms for line length and for the groups of syllables: iambic (weak before strong), trochaic (strong before weak) and anapaestic (double weak before strong).
} 


\section{The Advent of $F_{V}$}

Vers libre, or free verse, first appeared in French in the 1880s and was imported into English poetry in the early years of the twentieth century ${ }^{27}$. I would argue that FV is metrical, albeit polymetric, because metre is the numerical regulation of language, and its distinguishing feature is the non-random division of language into measured units that are not found in prose. There are, in fact, three ways of numerically regulating anything: the first is to make all the numbers the same (as is the case with the line lengths of most traditional verse), the second is to make them all different (a very rare practice even among FV poets), and the third is to make the numbers either the same or different depending upon the aesthetic effect the poet requires ${ }^{28}$. The last is the mode of versifying that almost all $\mathrm{FV}$ poets employ, and it radically alters the ratio of matches to contrasts in verse, making it more like that found in prose. Previously English poets had much more often matched than contrasted lines, beats, intervals, and syllables; in FV contrasts of all of these units play a far more important role.

The units remain the same, because they are dictated by English phonology, but FV poets employ those units in very different ways from poets composing regular verse. I shall examine each of the linguistic units involved when explaining the first principle of FV below. But the most important

$\overline{27}$ A concise account of the advent of vers libre / verso libre as an international phenomenon can be found in UTRERA TORREMOCHA, María Victoria: Historia y teoría del verso libre. Seville: Padilla Libros, 2001, pp. 74-97.

28 An example of aesthetic choice in versifying is feminine rhymes: French and Italian poets at first mixed masculine and feminine rhymes freely, but many later French poets strove to alternate them, while Italian poets gradually adopted the policy of making all their rhymes feminine. In English Sidney and Spenser eschewed feminine rhymes altogether, while Shakespeare employed them freely in most of his sonnets, but in Sonnet 20 used only feminine rhymes, thus reinforcing his theme of redundant appendages; for the sonnets of William SHAKESPEARE (b. 1564, d. 1616) see William Shakespeare: Complete Works, IV, ed. Peter Alexander. London: Collins, 1958. 
way in which FV differs from other verse can be seen clearly from Table $\mathrm{C}$, which lists the different types of verse that can be composed in a language deriving its rhythm from beats and intervals. The types of verse can classified according to a simple Latin square where the four variables are beats and intervals, matching (represented by the binary digit 1) and contrasting (represented by the binary digit 0 ):

\section{Table C: Metrical paradigm}

$\begin{array}{rc}\text { Beats } & \text { Intervals } \\ 1 & 1 \\ 1 & 0 \\ 0 & 1 \\ 0 & 0\end{array}$

This table shows clearly shows that FV simply completed a paradigm of metrical possibilities that were inherent in the English language.

The reasons why FV emerged and became established when it did were social: first, the twentieth century was an era when most Westerners felt the need to break with convention, and when people of all classes became inured to surprise and shock. Secondly, a change in poetry-reading habits made irregular and unpredictable verse viable in a way that it had not been before. I shall return to the second of these points in discussing the third principle of FV.

\section{The Principles of Fv}

Many of the great pioneers of FV offered explanations of how their own verse worked but, as Charles Hartman noted, every one of these systems breaks down when applied to other poets' $\mathrm{FV}^{29}$. This, I believe, is because poets observe some principles consciously, some unconsciously; experienced poets, in particular, versify intuitively and rely upon their ear.

${ }_{29}$ See HARTMAN, Free Verse, cit., p. 44. 
Each of the pioneers, therefore, made different choices from the common features of FV when offering an explanation of his / her own. There are, nevertheless, important features shared by all FV, and I shall try to identify and, if possible, quantify the principles that would account for them.

I FV matches and contrasts linguistic units at three levels

The three linguistic units are lines, cola, and the rhythmic units that I call beats and intervals, but which many metrists call feet. All three units are employed in regular verse, but FV poets employ each of them in a new way. I shall examine each in turn.

In strict English metres poets match lines in major ways (length, overall rhythm) and contrast them in minor ones (rhythm at specific points, tension). In FV, however, the poet may choose either to match consecutive lines or to contrast them, and may do the latter with extreme violence. Philip Hobsbaum argues that linear contrasts are the essence of what he terms 'free verse proper' ${ }^{30}$. He follows Peter Redgrove in dividing lines into two types, 'thrusting' and 'receptive' lines, a Freudian simplification that he then has problems in justifying. In his argument he hovers between two hypotheses: (1) 'thrusting' lines are characterized by the number of heavy stresses (p. 113), and (2) 'thrusting' lines contain 'declarations' and 'receptive' lines contain 'qualifiers' (p. 117); but in his examples the rhythms of the lines he quotes provide the most salient matches and contrasts, and he comments extensively on their rhythmic features. In fact, many types of match / contrast occur in FV, not just of stress strength and semantic import, but also of things like diction (for example, antonyms may be used to open and close a line, or monosyllabic lines may be contrasted with polysyllabic). The most important linear contrasts in FV, however, are those of length and of rhythm, and the first may be observed in instances (27) and (28) below, where a five-beat line is followed by a line

$\overline{30}$ See HOBSBAUM, Metre, Rhythm and Verse Form, cit., pp. 103-17. 
with a single beat. Linear contrasts of this type are one of the most obvious distinguishing features of FV.

The second linguistic unit employed by FV is the colon, the subdivision of the line created by a grammatical boundary greater than the word. In regular English verse cola often contrast; thus iambic pentameters subdivide into two cola, one of two beats and the other of three. The reason that English poets have neglected the alexandrine (the other metre in the Spenserian stanza) is probably that its $3+3$ beats do not offer the $2+3$ or $3+2$ variety of the pentameter ${ }^{31}$. Matching and contrasting cola are the basis of some of the oldest surviving verse, usually termed phrasal verse, where two cola / phrases (occasionally three) are linked to form a line that has no other regularities. This is the metre of Ancient Egyptian, Chaldean, and Semitic verse, and we know it best from the Bible, because phrasal verse translates from one language into another. Several major poets have composed phrasal verse in English, the most notable being William Blake in the eighteenth century and Walt Whitman in the nineteenth ${ }^{32}$. The following lines are examples of English phrasal verse; they come from Whitman's Leaves of Grass ('Song of Myself', I: 1, 3, \& II: 10):

(24) I ce-le-brate my-self, // and sing my-self

(25) For e-very a-tom be-long-ing to me // as good be-longs to you

(26) My res-pi-ra-tion and in-spi-ra-tion, // the bea-ting of my heart// the pas-sing of blood and air through my lungs

$\overline{31}$ Alexander POPE (b. 1688, d. 1744) described the alexandrine as slow and heavy in his Essay on Criticism (line 357), but later demonstrated that it could sometimes be light and rapid (373); see his Collected Poems, ed. Bonamy Dobrée. London: Dent, 1924. French poets make the alexandrin a more varied and interesting metre by placing their strong syllables unpredictably; see PENSOM, Roger: Accent and Metre in French. Bern: Peter Lang, 2000. The finest alexandrines in English are those of Ernest DOWSON (b. 1867, d. 1900), who achieved similar variety by caesura variation in "Non Sum Qualis Eram"; see The Oxford Book of English Verse, 1250-1950, ed. Helen Gardner. Oxford: Clarendon Press, 1972, p. 807.

32 For the phrasal verse of William BLAKE (b. 1757, d. 1827) see The Poems of William Blake, ed. W. H. Stevenson \& David V. Erdman. London: Longman, 1971; for that of Walt WHITMAN (b. 1819, d. 1982) see A Choice of Whitman's Verse, ed. Donald Hall. London: Faber and Faber, 1968. 
Note how the two matched phrases in (24) are relatively short, while in (25) the first phrase contrasts with the second by being much longer; and instance (2) contains three phrases of very different lengths. In this particular passage the number of beats in each phrase $(3,2,4,3,4,2,4)$ provides more contrasts than matches.

Whitman's work has inspired many FV poets, none more so than the American poet, Allen Ginsberg ${ }^{33}$. His most famous poem 'Howl' has lines of unprecedented length, as befits a prolonged outcry against all the evils of a society. Ginsberg avoids the pitfall of lapsing into prose by matching phrases within these long lines. For example, line 75 (beginning 'to recreate' and ending with 'endless head') contains fifty-eight syllables, but it has a powerful rhythmic pattern, deriving from its division into seven phrases, each with three major peaks of stress. Phrasal matches are thus a means of extending the line to unprecedented lengths without it becoming amorphous. The English metre known as Skeltonics also attracted new attention in the period when FV was becoming established, and that too is little more than rhymed phrasal matching ${ }^{34}$, The revival of ancient phrasal metre was thus one of the most interesting features of twentieth-century versifying.

The third level at which FV matches and contrasts linguistic units is that of beats and intervals, as noted in section 7 above. I shall explain the practical implications of this in more detail in the sections devoted to principles IV and V.

II $\mathrm{FV}$ is polymetric and autonomous

The following quatrain, which closes Lawrence's famous

33 For "Howl" by Allen GINSBERG (b. 1926, d. 1997) see GINSBERG, Allen: Selected Poems. Harmondsworth: Penguin Books, 1996.

34 John SKELTON (b. ?1460, d. 1529) invented this form; see, for example, his most famous poem, "Philip Sparrow", in his Complete Works, ed. Philip Henderson. London: Dent, 1931. Note that Skelton often gave a series of lines the same number of beats, but otherwise most of the matches in this poem are of rhyme alone. For an example of modern unrhymed Skeltonics see "The Halls of Bedlam" by Robert GRAVES (b. 1895, d. 1985), in his Collected Poems. London: Cassell, 1965, pp. 125-27. Many FV poems with ultra-short lines resemble unrhymed Skeltonics with more daring use of enjambment; see note 44 below. 
poem 'Snake', illustrates the way that FV lines vary in their number of beats and size of interval:

(27) And so, I missed my chance with one of the lords

(28) Of life.

(29) And I have some-thing to ex-pi-ate;

(30) A pet-ti-ness.

These lines contain 5, 1, 3, 1 beats, and the intervals in the poem also vary in size: seven of the first eight intervals in the quatrain contain a single syllable, giving a sequence that is broken only by the two syllables between 'one' and 'lords'; but each of the last three beats is followed by two syllables. This strophe has one of many structures found in the poem and its lines represent only three of the poem's line lengths; Tables D and E below quantify both these features for the whole poem:

TABLE D: 'SNAKE': STROPHE LENGTH IN LINES

\begin{tabular}{|c|r|r|r|r|r|r|r|r|r|}
\hline $\begin{array}{c}\text { Stro- } \\
\text { phe } \\
\text { Length }\end{array}$ & 2 & 3 & 4 & 5 & 6 & 7 & 8 & 9 & Total \\
\hline Number & 3 & 5 & 4 & 3 & 1 & 1 & 0 & 1 & 18 \\
\hline
\end{tabular}

These eight lengths of strophe occur in no particular order, and the next table shows the extent to which this poem is polymetric:

TABLE E: 'SNAKE': LINE LENGTH IN BEATS

\begin{tabular}{|c|c|c|c|c|c|c|c|c|c|c|}
\hline $\begin{array}{c}\text { Line } \\
\text { Length }\end{array}$ & 1 & 2 & 3 & 4 & 5 & 6 & 7 & 8 & 9 & Total \\
\hline Number & 3 & 6 & 10 & 10 & 19 & 12 & 7 & 2 & 5 & 74 \\
\hline
\end{tabular}

The line lengths occur in almost as unpredictable an 
order, but each strophe contains only a few line lengths. The contrasts between lines are unpredictable and much more dramatic than those in Dryden's Alexander's Feast; 'Snake' is not only polymetric, it is autonomous: the poet alone has decided the length and rhythm of each line in the poem. This is what makes a dolnik free, but the number of FV poems that can be classed as free dolniks should not be overestimated, as I shall demonstrate ${ }^{35}$.

\section{III $\mathrm{FV}$ is verse for the eye as well as the ear}

Note that when extreme line lengths are employed unpredictably, as in 'Snake', only unnaturally long pauses between lines can make their boundaries immediately clear to an aural audience. In the course of the twentieth century Western poetry-reading habits changed: as people became detribalised, scattered, and isolated, so most of them experienced poetry visually, on the printed page, rather than aurally in a princely hall, a pub, or a parlour. The fixing of the text in print enabled them to absorb sharp contrasts and appreciate subtle matches that previously had disorientated, or been lost upon, poetry's aural audiences ${ }^{36}$. Derek Attridge first pointed out the importance of this visual element in 1987 and without it FV is unlikely to have become so ubiquitous ${ }^{37}$.

At its most extreme, this visual element prompted poets to compose poems that formed a pattern on the page; George Herbert had, of course, composed such poems in the seventeenth century, but in modern times one of the first poets to do so (as more than an isolated joke) was the French poet Apollinaire $^{38}$. One of the most notable to do so in English

${ }_{35}$ This autonomy is the feature that FABB and HALLE comment upon in my opening reference, but most FV poets exercise their autonomy by crafting far more matches in line length and rhythm than Lawrence's does in this poem.

${ }^{36}$ Although, from the eighteenth century onwards, only folk verse was primarily oral, until the end of the nineteenth century art verse was recited often enough to deter poets from essaying forms whose regularities escaped the ear, and thus could be labelled 'doggerel'.

37 See ATTRIDGE, "Poetry Unbound", cit.

38 For the poems of George HERBERT (b. 1593, d. 1633) see The Complete English Poems of George Herbert, ed. C. A. Patrides. London: Dent, 1974; for an 
was Dylan Thomas, who composed a series of poems entitled 'Visions and Prayers', which are all shaped like diamonds or $\operatorname{crosses}^{39}$. An American poet, Marianne Moore, on the other hand, invented something less conspicuous but more influential: visual syllabic verse, in which she made a pattern in the number of syllables in her lines as counted by the eye (or on the fingers $)^{40}$. This differed from previous (aural) syllabic verse in two ways: it took no account of the position of the final stress in the line and it included lines that are too long to be counted by ear. She probably achieved this regularity, which audiences are unable to hear, by adding and subtracting monosyllables after composition. Nevertheless, she inspired many imitators, and one of these was W.H. Auden, a poet who on several occasions had expressed doubts on the viability of syllabic verse in English ${ }^{41}$.

The enhanced visual element in FV also had the benefit of increasing the impact and effectiveness of enjambment. For example, only a highly artificial delivery of instances (27) and (28) above will convey the enjambment in 'the lords / of life' to an aural audience, but the severance of the intonational phrase leaps from the page visually. Many FV poets cultivated even more unusual enjambments; thus Lawrence could have divided his lines 'the lords of / life' or 'the / lords of life'; each of these would have produced a different effect, both semantically and rhythmically. An extreme example of striking enjambment occurs in Wallace Stevens's poem 'It Must Give

example of a visual poem see "Easter Wings" (p. 63). For the visual verse of Guillaume APOLLINAIRE see his Selected Poems, ed. \& tr. Oliver Bernard. Harmondsworth: Penguin, 1965.

39 These visual poems by Dylan THOMAS (b. 1914, d. 1963) appear in his Collected Poems 1934-1952. London: Dent, 1966, pp. 129-40.

40 For the collected poems of Marianne Craig MOORE (b. 1887, d. 1972) see The Complete Poems of Marianne Moore. New York: Macmillan, 1967; for a demonstration of how difficult it is to count the syllables of her longer lines see the misquotation from her work in HOBSBAUM: Metre, Rhythm and Verse Form, cit., pp. 78-79.

41 Thus, for example, Wystan Hugh AUDEN (b. 1907, d. 1973) composed his poem "In Memory of Sigmund Freud" in quatrains with lines of 11, 11, 9, \& 10 visual syllables. But AUDEN also gave these lines regularity to the ear by making the first two invariably masculine and the second two invariably feminine; see his Collected Shorter Poems, 1927-1957. London: Faber and Faber, 1966, pp. 166-70. 
Pleasure', where he separates two sensory organs from their governing preposition: 'of / his eye' and 'of / his ear' (lines 112-14). In the iambic pentameter the only place that the poet can enjamb is after syllable ten; in FV the poet can spot an effective enjambment and craft the line lengths around it.

IV FV contains more contrasts than other verse, (but many more matches than prose)

This is true of both the length and rhythm of FV lines, as Tables $\mathrm{F}$ and $\mathrm{G}$ below demonstrate. Table $\mathrm{F}$ gives statistics for two line lengths in six poems by two of FV's most famous pioneers, Eliot and Pound, and it also shows the proportion of their intervals that contain other than one $(\sim 1)$ syllable $^{42}$.

Table F: Pound's and Eliot's FV (all figures are percentages)

\begin{tabular}{|c|c|c|c|}
\hline Poem & $\begin{array}{c}\text { Five-beat } \\
\text { Lines }\end{array}$ & $\begin{array}{l}\text { Three-beat } \\
\quad \text { Lines }\end{array}$ & $\begin{array}{l}\sim 1 \text { syllable } \\
\quad \text { Intervals }\end{array}$ \\
\hline 'Altaforte' & 59 & 3 & 43 \\
\hline 'Prufrock' & 52 & 17 & \\
\hline 'The Burial of the Deac & 64 & 6 & 35 \\
\hline Ash Wednesday I \&V & 40 & 20 & 21 \\
\hline 'CANTO' I & 11 & 50 & 53 \\
\hline 'CANTO LXVI' & 46 & 6 & 77 \\
\hline
\end{tabular}

These figures can be compared with those that would be obtained by an analysis of strict iambic pentameters, where 100 per cent of lines are five-beat and only \pm 2 per of intervals have other than one syllable. I could make several points about the chronology of these poems and the difference of the two poets' FV styles, but for the present the most important fact emerging from the table is that even FV poems have a dominant line length (sometimes two lengths), a dominant rhythm, or both. Thus 'Prufrock' has a dominant iambic rhythm, and

\footnotetext{
${ }^{42}$ My analysis of these poems by Thomas Stearns ELIOT (b. 1888, d. 1965) is based on the text of his Collected Poems, 1909-1962. London: Faber and Faber, 1963; to give line samples of comparable length I included only sections I and IV of Ash Wednesday. My analysis of P POUND's poems is based upon the texts found in his Selected Poems, ed. T. S. Eliot. London: Faber and Faber, 1967, and Selected Cantos. London: Faber and Faber, 1965.
} 
all three poems by Pound have more triple time (the rhythm produced by making every third syllable a beat) than prose ${ }^{43}$.

Many twentieth-century poets composed FV poems in which five- and / or three-beat lines were dominant, but poems dominated by two-beat and four-beat lines were also common. Thus, for example, 60 per cent of the lines in William Carlos Williams's well-known poem 'The Crimson Cyclamen' have two beats ${ }^{44}$. The dominance of one line length may be almost total, as in Wallace Stevens's poem 'The Man with the Blue Guitar', where 98 per cent of lines have four beats ${ }^{45}$. Most FV poems have a dominant line length or rhythm, like those noted above, and poems like Lawrence's 'Snake', where only a quarter of the lines have the mode number of beats (five), are very rare. It may be appropriate to describe 'Snake' as a 'free dolnik', but 'The Crimson Cyclamen' is more accurately a 'predominantly two-beat dolnik', and 'The Man with the Blue Guitar' merits the description a 'loose iambic tetrameter'.

One design, the five-beat dolnik, is dominant in so many twentieth-century poems that they are often described as being in flexible pentameters. This is the metre of instances (8)-(10) above by Webster, whom Eliot claimed as one of his metrical models (although thirty years before the publication of The Waste Land Robert Bridges had used this metre in his most famous poem, 'London Snow') ${ }^{46}$. Later twentieth-century poets blended not only iambic pentameters and five-beat dolniks in this metre, but also lines that are decasyllables to the eye, yet have only four beats. This metre is a true hybrid

$\overline{43}$ The technique known as probability modelling compares the frequency with which linguistic features occur in prose and in any given poem. Exactly two syllables occur in approximately 34 per cent of the intervals in English prose; see TARLINSKAJA, Marina: Strict Stress-Meter in English Poetry Compared with German and Russian. Calgary: Univ. of Calgary Press, 1993, p. 46.

${ }^{44}$ My analysis of this poem by William Carlos WILLIAMS (b. 1883, d. 1963) is based on the text of The Collected Poems of William Carlos Williams, ed. A. Walton Litz \& Christopher MacGowan, 2 vols. Manchester: Carcanet 1987-88.

45 My analysis of poems by Wallace STEVENS (b. 1878, d. 1955) is based upon The Collected Poems of Wallace Stevens. London: Faber and Faber, 1965.

${ }^{46}$ For "London Snow" by Robert BRIDGES (b. 1884, d. 1930) see Poetical Works of Robert Bridges Excluding the Eight Dramas \& 'The Testament of Beauty'. London: Oxford Univ. Press, 1936, pp. 265-66. 
because many poets employing it admit regular lines of various types as well as five-beat dolniks. But the flexible pentameter is an entirely five-beat metre in the verse of some poets, including Wallace Stevens. Much of his early verse was in canonical iambic pentameters, but by the time he composed 'An Ordinary Evening in New Haven' in 1949 his five-beat line had become much more flexible: about a quarter of the intervals in that poem contain other than one syllable and only about a quarter of its lines are canonically iambic ${ }^{47}$. Later in the century many poets settled for rather less variety in their flexible pentameters, as can be seen from Table $\mathrm{G}$, which analyses ten poems in this metre by six major poets ${ }^{48}$. It specifies the percentage of lines that have five beats and within them the percentage of canonical iambic pentameters; it also gives the percentage of intervals that contain other than one syllable.

Table G: Twentieth-Century Flexible Pentameters

\begin{tabular}{|c|c|c|c|}
\hline $\begin{array}{l}\text { Name } \\
\text { of Poet }\end{array}$ & $\begin{array}{l}\% \text { of } \\
\text { Five-beat Lines }\end{array}$ & $\begin{array}{l}\% \text { of } \\
\text { Canonical Lines }\end{array}$ & $\begin{array}{l}\% \text { of } \\
\sim 1 \text { Intervals }\end{array}$ \\
\hline Stevens & 100 & 27 & 26 \\
\hline Auden & 89 & 80 & 21 \\
\hline Hope & 99 & 78 & 14 \\
\hline Hughes & 88 & 18 & 20 \\
\hline Heaney & 82 & 53 & 14 \\
\hline Pinsky & 100 & 62 & 15 \\
\hline
\end{tabular}

This table shows that none of these poets employed as few canonical lines as Stevens, or as many intervals with other than one syllable. Their pentameters were thus less flexible,

\footnotetext{
$\overline{47}$ The text analysed is the shorter version of the poem composed in 1949.

${ }^{48}$ My analysis of these poems by Thomas Stearns ELIOT (b. 1888, d. 1965) is based on the text of his Collected Poems, 1909-1962. London: Faber and Faber, 1963; to give line samples of comparable length I have included only Sections I and IV of Ash Wednesday. My analysis of poems by Ezra POUND is based upon the texts found in his Selected Poems, ed. T. S. Eliot, cit., and Selected Cantos, cit.
} 
but most of them balanced this by including lines with other than five beats.

Among such lines are a number of four-beat visual decasyllables; in Seamus Heaney's 'Glanmore Sonnets' these reach a percentage well into double figures ${ }^{49}$. For copyright reasons I shall use two of Lawrence's lines to illustrate this combination of iambic pentameter and four-beat visual decasyllable:

(31) and Di-o-ny-sos, young and a stran-ger

(32) leans listen-ing on the gate, in all res-pect

These lines close the short poem 'The Middle of the World', collected posthumously in his Last Poems (1932). Such combinations are extremely rare in Lawrence's FV, although his verse ranges from free dolniks to regular metres.

V FV's matches are subtler than those of other verse

The Waste Land (1922) provides many good examples of the subtler matching of whole lines, and the first of these subtler forms is a feature that I term local matching: within the poem groups of consecutive lines exhibit the same structure. Eliot opens section I, 'The Burial of the Dead', with a new metre of his own invention; it is strongly trochaic and its structure is based on that of an old favourite, the trochaic tetrameter catalectic or 'seven', which has four beats, all but the last followed by a one-syllable interval ${ }^{50}$. Eliot invents an entirely new metre by adding another trochee to this line, making it five-beat with a stress-clash between the last two beats. For copyright reasons I shall illustrate Eliot's metre by a line plus a foot from the opening of a famous poem by

${ }_{49}$ Thus, for example, sonnet III (Heaney, p. 111) opens with two visual decasyllables, and their natural peaks of stress fall on syllables 2, 5, 9 and 2, 4, 6, 9 respectively.

50 See, for example, SHAKESPEARE's lyric beginning "Now the hungry lion roars" from Midsummer Night's Dream, v, I. 360-79, in The Complete Works, vol. 2, cit. 
Leigh Hunt ${ }^{51}$ :

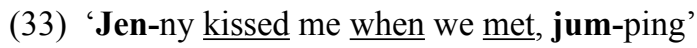

Eliot maintains this trochaic rhythm, working variations upon it, for seven lines. Soon, however, he forsakes the trochaic rhythm and most of the remainder of the poem is iambic. A similar short dalliance with one metre or rhythm before moving on to another characterizes many of the twentieth century's best-known FV poems.

Another subtle form of matching lines is to include a line (consciously or unconsciously) in a regular metre with which readers are likely to be familiar. I term this external matching and it can be seen in instances (27) and (28), quoted. The first of these lines is a five-beat dolnik that is almost a canonical pentameter, and the two lines together bear a strong resemblance to an alexandrine, but neither matches any line in the poem itself. The epitome of external matching is a practice popularised by Eliot in 'The Burial of the Dead': he included famous lines from poems in six different languages in a variety of metres. Eliot often distorts the metre of the line that has a regular external match; for example, in a later section of The Waste Land, 'Death by Water', Eliot evokes two metres in the opening line: its ten syllables are a distortion of the iambic pentameter, because they contain four beats linked by alliteration (Phle-, Phoe-, for-, dead), as in Old English accentual verse $\mathrm{e}^{52}$.

Local matches, external matches, and distortions are all extremely common in FV, and their inclusion is partly motivated by the poet's need to reassure readers that the text is verse and not prose. Although chopped-up prose has at times been marketed successfully as FV, few critics and serious students of poetry have been deceived by it, because they detect that the lines have not been crafted in accordance with any prin-

$\overline{51}$ This poem by James Henry Leigh HUNT (b. 1784, d. 1859) can be found in most popular anthologies; see, for example, The Oxford Book of English Verse, cit., p. 559.

52 This line opens Part IV of The Waste Land; for copyright reasons I am unable to quote Eliot's poetry in any publication that may be sold in the United Kingdom. 
ciple, and thus lack what Philip Hobsbaum calls 'rhythmic virtues ${ }^{53}$.

VI FV forms part of a metrical continuum

The French poet Mallarmé regarded FV as a revolution after which poets would resume composing regular verse that was all the better for the shaking up it had received; and T. S. Eliot deplored the chaos that followed his experiments and trusted that a new metrics with new norms would emerge from the FV experience ${ }^{54}$. Both poets were justified in their beliefs: the regular metres that twentieth-century versifiers employed were usually looser and more innovative than nineteenth-century verse had been; and the new metrics that Eliot hoped for has been achieved in the peaceful coexistence of FV and regular metres in the same poem. This can be seen from Table $\mathrm{G}$ above, which showed that many younger poets included strict iambic pentameters and lines of other lengths and types in the same poem. FV versifiers always have canonical lines of every type available for external matching, and they can also balance greater variety in their line lengths and rhythms by matches at strophe level, as in regular verse, and at colon level, as in the verse of the Ancients.

A good place to observe the coexistence of $\mathrm{FV}$ and regular metres is in the poetry of Dylan Thomas, whose wildly innovative diction has over-shadowed his metrical craftsmanship in the public's perception. Thomas composed most of his poems in stanzas, usually combining lines of different lengths in a regular order, linked by some form of rhyme ${ }^{55}$.

53 See HOBSBAUM: Metre, Rhythm and Verse Form, cit., p. 90. For an example of satirical chopped-up prose that has been very successfully marketed see SEELY, Hart: Pieces of Intelligence: The Existential Poetry of Donald H. Rumsfeld. New York: Simon \& Schuster, 2003.

54 See STEELE, Timothy: Missing Measures: Modern Poetry and the Revolt against Meter. Fayetteville: Univ. of Arkansas Press, 1990, pp. 36 \& 279.

55 In most of his poems Thomas, like many twentieth-century poets, favoured subtler matches of line-final syllables to rhyme. Thus, for example, in the first sonnet of "Altarwise by Owl-Light" he employed consonance in 'house / news' and 'word / said', weak rhyme in 'shelter / cancer', and an ancient Welsh form of phoneme matching known as cynghanedd in 'furies / fairies' and 'wounds / winds'; he used only one full rhyme in the sonnet, 'leg / egg'. 
The prevailing rhythm of many is iambic; for example, 'The Force that through the Green Fuse Drives the Flower' (p. 8) combines two iambic line lengths, and 'A Grief Ago' (p. 49) combines three. But many other poems are in dolniks, with a single or predominant line length; for example, 'And Death Shall Have No Dominion' (p. 62) is a four- and 'In My Craft or Sullen Art' (p. 120) a three-beat dolnik. Even in his regular forms, however, Thomas often includes deviant lines, occasionally of an unexpected length, but more often with a dramatic change in rhythm. Thus 'Altarwise by Owl-Light' (pp. 65-69) is a sequence of ten sonnets in iambic pentameters, but each sonnet has at least one line that is in sharp rhythmic contrast to the others. These lines may even be as deviant as Shakespeare's famous 'Never, never, never, never, never' (King Lear, V, III. 308), which is at the same time a headless feminine line, a trochaic pentameter, and a visual decasyllable. Thomas's versifying demonstrates that we should not regard FV and regular verse as separate systems, but as parts of a new system in which any given poem may have more of the characteristics of one mode of versifying than of the other.

$\mathrm{FV}$ and regular verse thus form a continuum, a range of metres running from the most regular to the least; individual poets can choose where on that continuum they wish to versify, and some make a different choice in every poem. The verse of the twentieth century may not all have been free, but its poets were: some chose to compose mainly in FV, others exclusively in regular metres, and many in both, often in hybrids between the two.

\section{Conclusion}

There are a number of important generalizations that can be made about FV and I have listed six of them above as a set of principles. I have little doubt that subsequent writers will discover more. The present list, however, should be sufficient to dispel the notion that FV is something vague and 
elusive that cannot be analysed in a logically rigorous way. $\mathrm{FV}$, I would argue, is not non-metrical, it is polymetric: an FV poem, far from having no verse design, has many, but most of them are dolnik, not stress-syllabic designs. And the poet is free to deploy them in any order he / she wishes. I also hope I have dispelled the notion that FV is totally different from what came before: regular verse not only predates $\mathrm{FV}$, it is a precondition of it. FV poets go one step beyond the loosest English metres and then, in order to distinguish their product from prose, reinforce it with a long list of devices derived from regular verse.

There is little justification for regarding $\mathrm{FV}$ and regular verse in English as two different systems; to employ a biological metaphor, FV evolved from regular verse, which then stubbornly refused to take the path to extinction. Today the two coexist to provide twenty-first century poets with a single, richer system. FV, the newer mode of versifying, became popular as a result of the change in poetry-reading habits around the time of its inception, helped by the zeitgeist of an age that became addicted to change. Nevertheless, most twentieth-century poets continued to write regular verse, at least some of the time. FV thus represents an expansion, not a negation of the existing repertoire, and has resulted in a wider range of metrical choice than poets have enjoyed in any previous period. Because the polymetry of FV offers an almost inexhaustible supply of new poetic forms, future poets will no doubt exploit its possibilities in ways beyond those I have described; and if this article can in any way help them in their enterprise it will more than justify the research that has produced it. 